\section{$\underset{\text { hommes }}{\text { \& migrations }}$}

\section{Hommes \& migrations}

Revue française de référence sur les dynamiques

migratoires

$1331 \mid 2020$

Femmes engagées

\title{
Olivia Elkaim, Le tailleur de Relizane
}

Paris, Stock, 2020, 352 p., 20,90€.

\section{Mustapha Harzoune}

\section{(2) OpenEdition}

1 Journals

\section{Édition électronique}

URL : https://journals.openedition.org/hommesmigrations/11876

DOI : 10.4000/hommesmigrations. 11876

ISSN : 2262-3353

\section{Éditeur}

Musée national de l'histoire de l'immigration

\section{Édition imprimée}

Date de publication : 17 novembre 2020

Pagination : 189

ISBN : 978-2-919040-52-0

ISSN : $1142-852 X$

\section{Référence électronique}

Mustapha Harzoune, "Olivia Elkaim, Le tailleur de Relizane », Hommes \& migrations [En ligne], 1331 |

2020, mis en ligne le 01 novembre 2020, consulté le 04 janvier 2023. URL : http://

journals.openedition.org/hommesmigrations/11876; DOI : https://doi.org/10.4000/

hommesmigrations. 11876 


\section{Le tailleur de Relizane}

Olivia Elkaim, Paris, Stock, 2020, 352 p., 20,90€

Relizane, du berbère «Ighil Izzan» («la colline brûlée»). «Cayenne» de l'Ouest algérien. Relizane, dans 


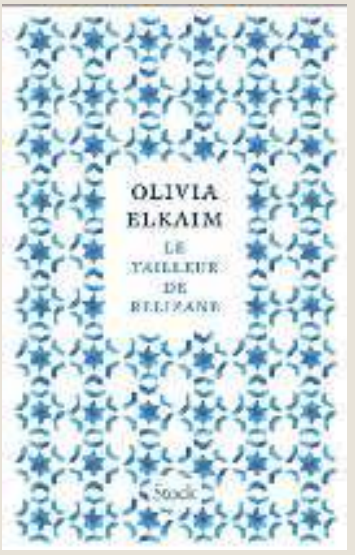

les années 1950, en pleine guerre d’Algérie. Quartier juif. Les Elkaim forment une fratrie: Marcel, Maxime et Léon dit «le Joyeux». Leur mère, Lella. «Mémé Lella» pour Pierre, l'aîné de Marcel - le père de la narratrice, longtemps traumatisé par ce conflit et les craintes pour son père, la difficile installation en France et la dépression de Viviane, sa mère. $\mathrm{Au}$ cimetière reposent les deux sœurs Clotilde; la première, morte à l'âge de quatre jours, et la seconde qui s'est suicidée à 15 ans pour échapper à un mariage. Marcel psychopompe entend Clotilde lui parler. Ces Berbères juifs, enracinés dans cette terre depuis des siècles, étaient «comme des frères avec les Arabes» avant le décret Crémieux. "Ce Crémieux [...] il nous a joué un sale tour à nous les Juifs algériens!» dit Maxime. À shabbat, le repas familial est mouvementé, engueulades et politique: Maxime accepte «le vent de l'Histoire», il sera le premier à partir. Léon ne fait plus de blagues, il se raidit. Marcel attend, espère. Toujours.

C'est donc Olivia, la fille de Pierre, qui, sept décennies plus tard, raconte cette part algérienne de la famille Elkaim, elle qui s'était évertuée à la refouler. Après lui avoir tourné le dos, la voici, au seuil de la quarantaine et dans les remous d'un divorce qui plonge dans l'Algérie de grand-papa. Le récit est livré en courts paragraphes où l'auteure mêle l'histoire passée des Elkaim (la guerre d'Algérie et l'arrivée en «métropole») et la sienne, moderne journaliste, parisienne au présent secoué de turbulences et de doutes qui s'amourache d'un certain « $B$ ». "Je ne voulais rien savoir, gommant leur histoire, leur mémoire, me promenant, aveugle et sourde, dans la nuit de mes origines. On pouvait vivre ex nihilo, et heureux, pensais-je alors. » Mais «l'Algérie persiste», dans les corps ou dans les goûts.

L'auteure cite un proverbe algérien: "Celui qui ne sait pas d'où il vient ne sait pas non plus où il ira. » Ainsi, ce récit en forme de retour sur les origines est aussi - surtout? - une sorte d'anamnèse, un détour obligé pour mieux vivre présent et devenir, (re)fonder une vie et une liberté de femme non sur l'ignorance mais sur la connaissance des origines. Pour mieux s'en abstraire. Sans forligner. Olivia Elkaim rejoint ici d'autres récits, à commencer par L'Art de perdre d'Alice Zéniter.

Le tailleur de Relizane, c'est le grand-père, Marcel, une sorte d'ovni dans l'Algérie coloniale. Lui ne manifeste aucune animosité envers les Algériens du cru, il parle l'arabe, passe du beth midrash à la médersa, embauche des «musulmans», discute avec Amirouche, le futur chef de la Wilaya IV. Enlevé une nuit d'octobre 1958 par l'Armée de libération nationale (ALN), il sera libéré, provoquant suspicion et hostilité chez les siens: "Ceux qui ont disparu ne sont pas revenus, pourquoi tu es rentré, toi?»

Quand la violence brûle l'édifice fragile des liens intercommunautaires, lui ne se laisse pas gagner par la rancœur. Juste par la tristesse, la nostalgie et ce sentiment d'impuissance de ces Juifs algériens ballottés dans les vents violents «d'une Histoire trop grande pour eux». Plus tard ces Juifs, Français de papiers, seront «les méprisés de la société française».

Olivia fouille la valise d'archives du grand-père, les clefs USB chargées de vidéos. "Tout était archivé», depuis des années, par son père. Elle fait revivre personnages et événements. Renoue avec ce passé qui la fonde. Elle veut aller plus loin. Partir en Algérie. Revisiter la ville, le quartier, la rue, la maison de Marcel. L'Algérie officielle le lui refusera. Olivia est... journaliste. L'État algérien n'a jamais apprécié cette profession. Allez le demander aujourd'hui à Khaled Drareni ou, avant, à Mohamed Benchicou. Ce n'est pas Olivia qui renouera avec l'Algérie mais un autre membre de la famille. Une rupture. Une ouverture. Une réconciliation. De souterraine, la transmission s'opère désormais à l'air libre. Pour avancer «sans [plus] se retourner». M. $\mathrm{H}$. 